\title{
The Policy Implementation Impact on Region Management
}

\author{
Tati Sarihati, Rannie Dyah K.Rachaju, Lusy Mukhlisiana
}

\begin{abstract}
The land function alteration happens massively at Kecamatan Cimenyan, an area in North Bandung Region or known as Kawasan Bandung Utara (KBU). KBU areas are important because it is located traverse 4 different regions, such as Bandung, Kabupaten Bandung, Kabupaten Bandung Barat, and Cimahi. The main function $\mathrm{KBU}$ areas to the cities and districts are very important, especially for water infiltration. It means that these areas are become the main water conservation land and also a flooding prevention area, not only for Bandung Raya region, but also for West Java Region. Land function alteration that happen in Kecamatan Cimenyan are encompass forest, plantation, dry land agricultural plant or known as TPLK conversion and water conservation land alteration into housing development, hotel chain business, and even change into mining area. That leads to environmental changes, such as soil erosion and sedimentation, overflowing river that leads to floods. It's all because the water conservation areas are getting smaller and smaller each day. Thus, this research aimed to analyse the policy implementation factors that affect the region management effectiveness, hindrance factor, and also the administration efforts at Kecamatan Cimenyan Kabupaten Bandung. An explanative method was used to analyse this research, and used cluster sampling to select the sample from 9 village and kelurahan in $\mathrm{KBU}$ region, Kecamatan Cimenyan Kabupaten Bandung in particular. And on every stage sampling are taken by simple random sampling method. The data of this research are examine using structure equation modelling (SEM), a procedure based on methods of successive interval. This research disclosed that the policy implementation that based on communication dimension, resources, disposition/support attitude and bureaucratic structure have a significant impact on the region management effectiveness. And the most significant dimension to determine the effectiveness of the region management was support/disposition dimension then followed by others dimension.
\end{abstract}

Index Terms: Policy Implementation; Effectiveness; Region Management.

\section{INTRODUCTION}

North Bandung Region or known as Kawasan Bandung Utara $(\mathrm{KBU})$ is an area that meant for conservation and cultivation area, as assigned in Peraturan Daerah Provinsi Jawa Barat Nomor 2 Tahun 2016 . This government policy

Revised Manuscript Received on September 22, 2019.

Tati Sarihati, Government Sciences program, Fakucty of Social and Political Sciences Universitas Langlangbuana Bandung Indonesia.

Rannie Dyah K.Rachaju, Communication Sciences program, Fakucty of Social and Political Sciences Universitas Langlangbuana Bandung Indonesia.

Lusy Mukhlisiana, Communication Sciences program, Fakucty of Social and Political Sciences Universitas Langlangbuana Bandung Indonesia. stated that KBU territory hold a significance and vital function to surrounding areas, considering its location traverse 4 different regions, such as Bandung, Kabupaten Bandung, Kabupaten Bandung Barat, and Cimahi. KBU main function are important because as a water conservation area that holds as a flood's prevention area and as a main fresh water spring supply which not only supplied Bandung Raya Region but also for West Java Province.

Even though KBU region are important to the surrounding area, but other area doesn't seem to upkeep with the situation. Land function alteration area are getting uncontrollable. The land is altered into housing development, hotel chain business, and even change into mining area, both legally or illegal mining. And this happen on conservation and cultivation area, which a restricted area for development or land function alteration.

Based on the Data from Geospatial Information Bureau on 2014, showed that $80 \%$ of KBU area have already been altered into buildings and privately owned. And only $20 \%$ of its area are left for water conservation, this led to flooding in southern Bandung region. This condition makes people wondering what are the function and roles of the government on this matter, especially how they handle the land function alteration in KBU.

Based on Ruswandi et al. research (2007), it describes that in the past 10 years (1992-2002) the cultivation land conversion in KBU have a concentric pattern. For area development matter, the region government tend to develop towards rural area. After the rural area being develop there are more people coming in and stay in that area, as the consequences the new activity needs more spaces for its non-agricultural activity. This result has some resemblance with Rani Nuraeni et al. research (2017), that showed the land utilization in Kabupaten Bandung have altered, where the dominant alteration pattern, shows that forest was turned into development area, plantation, TPLB and TPLK become a development area. The significance factors that statistically weigh to the land alteration from cultivation land into development area are agricultural allocation, economic facility growth, PDRB growth (Brute Regional Domestic Product), hillside area with $<5 \%$ slope and infertile land.

Environmental conditions in the KBU, especially at Kecamatan Cimenyan, Kabupaten Bandung is quite disturbing. Environmental damage continues to occur as the impact of the land exploitation. Kecamatan

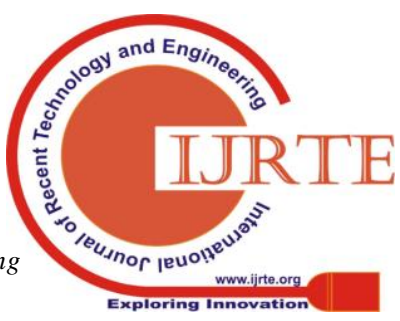




\section{The Policy Implementation Impact on Region Management}

Cimenyan, at the beginning was a green area and intended for water conservation area, but now has changed drastically into housing settlements, even many new buildings are being develop, such as housing development in various clusters, restaurants and cafes as well as tourist attractions, which makes land conservation function altered and not being utilize as it should be.

Based on field observation, we did find some problems occurred in land allocation at Kecamatan Cimenyan, such as:

1. The large number of developments that does not comply with the functions of the land that has been set.

2. Alteration land function that leads to environmental damage in the area underneath increased and the decreasing environmental carrying capacity in shoring up the community wellbeing.

3. The large number of developments that do not comply with regulations

4. The land construction and development permit are still being issued, even though there's been a decision from the Government that the authorizations or permit should be stopped.

This phenomenon as well as the problems which influenced the research aspects, it can be formulated into several problem as follows:

1. How significance is the influence of policy implementation against the effectiveness of land management in Kecamatan Cimenyan, Kabupaten Bandung.

2. The policy implementation dimension which have a significance influence to the effectiveness of land management in Kecamatan Cimenyan, Kabupaten Bandung.

3. The effectiveness of control dimensions which influenced the area mechanism policy implementation in Kecamatan Cimenyan Kabupaten Bandung.

Questions above are verified through several stages, at the first stage is through deductive approach with a rational hypothesis, but it is still a provisional answer. Then the answer will be confirmed further in the empirical through inductive reasoning.

This research intends to render the influence of policy implementation in contrast to the effectiveness of land management in Kecamatan Cimenyan Kabupaten Bandung, by describing and analysing the dynamical elements as shown in problem identification.

The purpose of this research consists of:

1. To analyse the systemic relationship pattern or model relationship between every dimension that influenced the policy implementation on land management.

2. To analyse the systemic relationship pattern or model relationship between every dimension that influenced the policy implementation on land management the most.

3. To analyse the systemic relationship pattern or model relationship between every public services dimension that have a dominant influence on the policy implementation, in order to increase the effectiveness in land management.

4. To analyse the policy implementation that can increasing the effectiveness of land management.

5. To clarify the land management phenomenon at Kecamatan Cimenyan Kabupaten Bandung.

In terms of science, we hope this research can contribute to enriched the public policy science, as well as to strengthen or improve the theories that have been used, and if possible, even further expectation is to create a new theory.

Last but not least, we hope this research can be useful to improve the effectiveness of environmental management, especially in the land utilization management that affect the community life quality. .

\section{LITERATURE REVIEW}

The policy is a Government's efforts to find out and solve the common problem. Many of the problems or dissatisfaction in society, but not all problems can be categorized as a common problem. Charles o. Jones suggested that a policy problem is an unrealized value, need or opportunity which, however identified, maybe attained thought public action.

Thus, can be taken as a conclusion that the policy is government's efforts to resolve the problems that exist in the general community. So, in the sense of that meaning, the effort which is done or not done by the Government relating to the public interest would be influential for the society.

But then Dunn suggests: "A policy system, or the overall institutional pattern within which policies are made, involves inter-relationship among three elements: public policies, policy stakeholders, and policy environments".

With regard to the success of an implementation, Edwards III started it by asking two questions, namely: “(1) What are the precondition for successful policy implementation? (2) What are primary obstacles to successful policy implementation?", and to answer it, then Edwards III suggested four factors that influence the implementation of public policy that is "Communications, resources, dispositions or attitude and bureaucratic structure".

Edward III stated that the implementation of the policy will be successful if there are four critical factors or variables that support, which includes:

\section{Communication}

Suggests an important role as a reference so that the policy executant know exactly what they will do. It means that communication can also be expressed by an order from superiors to the policy executants so the application of the policy is not out of the desired target. Thus, such communications should be stated in a clear, precise and consistent.

\section{Resources}

This variable not only includes the human resource factor/sheer civil servant but also includes the ability of other material resources to support the implementation of

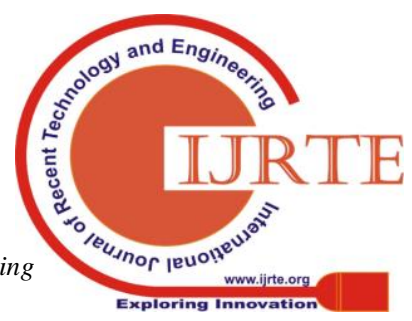


the policy. Adequate resources and meet the qualifications will result in the implementation of appropriate and effective policies.

The disposition or attitude of executant

This variable is defined as a desire or agreement among executant to implement policy. If the application of the policy is implemented effectively, the executant not only have to know what they should do, but they also must have a willingness and desire to implement it.

Bureaucratic structure

The last variable that has an impact on the implementation of the policy, especially in the sense that the implementation of the policy will not work if there is a weakness in the structure of the organization. In this case there are two characteristics of a bureaucracy that is common, that the use of routine procedures and attitudes, as well as fragmentation in responsibilities among the various organizational units.

In the context of the land management being organized by the local government, Epstein stated that: "Effectiveness refers to the degree to which services are responsive to the needs and desires of the Community ". Effectiveness relates to the level of how services are being responsive in fulfilling the needs and desires of the community. With respect to such matters, for the measurement Epstein explained that: "In measuring effectiveness, a government looks out to the public to determine the impact of services on community condition". Thus, in measuring area management that held by the Government should give its attention specifically on the possibility that the service will have an impact to the conditions and needs of the community.

Much further Epstein describes the efforts of area management measurements that held by the local government into four (4) dimensions, namely:

\section{1) Measures of community condition:}

Are important measures of effectiveness as they are most explicit measures of community need. These are generally the least effectiveness measures that are controllable by local services, so it is important to supplement with other, more controllable measures of effectiveness;

\section{2) Measures of service accomplishment category:}

Service accomplishment measures can include both quantity and quality considerations; the number (or percentage) of people from target population reached by the programme to some defined and the impact of the programme upon the client is reached;

\section{3) Measures of citizen or client satisfaction and perception;}

Cover satisfaction with public services and perception of community conditions on the part of citizens in general or specific clients or target groups of particular programmes;

\section{4) Measures of the unintended adverse impact of a} service on the community;

Examine the extent to which public services create needs or problems that might to otherwise exist or unintentionally aggravate existing problems.
Referring to the concept above, the measurement of the effectiveness of the services that held by local governance should be based on these dimensions:

Services compliance with the conditions of community; The services compliance is being measure with the conditions of the community were include a variety of conditions to expect or not to expect by the community with regard to the type of services concerned. Among them are associated with data that shows the range of services related to the service or data area data on the large number of underserved communities as well as the accuracy of the services in accordance with the qualification needs of the community that should be served.

The achievements of Services; Measurements on the achievements of services are complementing the measurement condition of the society. Both of this measurement will make a better bar to set and integrated in the measurement of effectiveness.

How much the society can be reached by the services programme compared with the targets set, and

The impact of the programme on the community which services can reach.

Public satisfaction and perception on the services provided;

Although the services have complied with the conditions of the society and the services achievements have been met, but public satisfaction and perception on the service provided is very important to consider. This is related to the possibility to get an idea of the actual attitude of topicality public, either in the specific scale i.e. customers or service users as well as society in General. One of the indications that can describe the satisfaction of society against the Government is given the large number of complaints submitted to the implementing institutions, community service and how to handle the complaint.

Reducing adverse impacts to the community.

Measurements against the adverse impacts associated with ability in controlling the negative impact or follow-up impact caused from the type of services provided. Measurements that can be used with regard to the efforts of "quality control" of organizing services types so as to prevent the possibility of any such adverse consequences for people's lives.

Implementation of policies oriented in an effort to ensure the achievement of results and further or in the future in accordance with the goals through a process that is in accordance with the mechanisms that have been defined and measured the ratio of the input provided with its success. This means that the implementation of policies aimed at looking at the level of a programme's effectiveness and efficiency of policies to solve the problem.

Pay attention to the background research, formulation of the problem, identification of problems, as well as the framework of thought that has been put forth, then the hypothesis is proposed as follows:

The extent of policy implementation influence 
against the effectiveness of the land management is determined by the communication, resources, disposition or attitude of the executant, and bureaucratic structure.

The dimension of the policy implementation has a lot of influence on the land management effectiveness that specified by the dimension of services compliance with the community condition, the services achievements, Public satisfaction and perception, to decrease adverse impact for the community.

The dimensions of the effectiveness of land management influenced by the dimensions of communication, resources, disposition/support and bureaucratic structure.

\section{METHODOLOGY}

\section{A. The object of Research}

The object of this research is the Kecamatan Cimenyan government with the elements that consist of government civil servant in 9 villages/kecamatan, community leaders who are not directly involved, but can provide information about the implementation of the land management policy that consist of: education personage, health personage, human resources (HR) personage, social economy notable, religious figures, the female leader, youth leader.

\section{B. Research Design}

The design for this research is an explanation research, in accordance with the objectives of this research which will explain the relationships between variables, namely the policy implementation and the effectiveness of land management.

The method used in this research was Explanatory Survey with the objective to analysing variable relations and test the hypothesis that was tested in the verification research. Basically, the research will test the results of deductive thinking or logical construct as a framework of thought by comparing the data and the information obtained in the field in as research results (inductive aspect).

\section{Population and Sample}

Withdrawal Technique of population in this research are all the elements related to the land management in Kecamatan Cimenyan Kabupaten Bandung such as the civil servant, the community and the developer in the area. Sample withdrawal technique that being used was stepwise cluster or cluster sampling. With the intention of giving odds on random rule to work, then the research sample is 200 people.

\section{Data Collection Techniques}

Data collection techniques being used are refer to the opinion of the Neuman, "quantitative, collecting data in the form of numbers". In the collection of quantitative data, conducted through a survey with questionnaire, which provide answers that have been categorized in the form of numbers, and using the pattern of Likert scale. For the purposes of data collection in the framework of Explanatory survey, then the techniques to collect data that being used are: 1) the observation, 2) the documentation and litreature study, 3) Interview, 4) questionnaire. Contextual usage of such data collection techniques for the analysis of the influence of variables through quantitative approach between data and information is measured by using a Likert scale. The acquisition of data and information is done by disseminating a questionnaire to 200 respondents and 28 informants.

\section{E. The Draught Test Analysis}

Hypothesis testing, done through a quantitative approach. Through quantitative, approach relationships who want to be analysed and explained the strong influence of a saw is variable against other variables that influence nature, either directly or indirectly. Then the interpretation of which is directed at the process of analysis of information and data for the purpose of describing the activities of individuals, groups and institutions with regard to the control of the region with research as a paradigm which shown in Figure 3.1. the following:

Fig. 1. Influence of structure between the variables bound.

Description:

$\mathrm{X} 1$ : Communication

$\mathrm{X} 2$ : Resources

X3 : Disposition/Executant Attitude

$\mathrm{X} 4$ : bureaucratic structure

Y1 : Community Condition

Y2 : Service accomplishment

Y3 : Citizen or client satisfaction and perception

Y4 : Unintended adverse impact of a service on the community

The statistical test used was the analysis of the Structure Equation Modelling (SEM). The purpose of this analysis is to describe the relationship a set of variables with other variables, so it can be known the extent of influence in each endogenous variable against exogenous variables directly stated by the scale of the determinant coefficient.

\section{RESULT AND FINDING}

\section{A. Research Result}

\section{1) Validation of The Policy Implementation Model Invalid Constructs}

The results of the data processing by using LISREL 8.5 software to model the measurement variable implementation of policies will be presented in the following table: 
Table 4.1 Variable Measurement Model to implementation Policy

\begin{tabular}{|c|c|c|c|c|}
\hline NO & Equation & $\begin{array}{c}\text { Varanasi } \\
\text { errors }\end{array}$ & $\mathbf{R}^{2}$ value & $\begin{array}{c}\text { t Value } \\
\text { (min 1.96) }\end{array}$ \\
\hline 1 & $\begin{array}{c}\mathrm{X} 1=0.69^{*} \\
\text { Implementation }\end{array}$ & 0.77 & 48 & 8,49 \\
\hline 2 & $\begin{array}{c}\mathrm{X} 2= \\
0.54^{*} \text { Implementation }\end{array}$ & 0.62 & 46 & 6,81 \\
\hline 3 & $\begin{array}{c}\mathrm{X} 3= \\
0.46^{*} \text { Implementation }\end{array}$ & 0.57 & 29 & 5,80 \\
\hline 4 & $\begin{array}{c}\mathrm{X} 4= \\
0.68^{*} \text { Implementation }\end{array}$ & 0.41 & 21 & 8,31 \\
\hline
\end{tabular}

- component Coefficient between variables with the technical feasibility of policy implementation is $r=$ 0.77 , this means there is a strong relationship between variables with the technical feasibility of policy implementation. Because the value of $r$ correlation $>0$, meaning a positive linear relationship occurs, the greater the value of the variable policy implementation with communication. Then for the coefficient's determinants of $48 \%$. This means that there is a strong influence among the policy implementation with technical feasibility. The value of the test statistic t-value 8.49 showed significant results ( $\mathrm{H} 0$ is rejected). To test the hypothesis of influence between the implementation of policies with technical feasibility retrieved tcount $=$ ttable $>8.49$, then Ho is rejected, meaning that there are influences of implementation of policies with technical feasibility. Component Coefficient between variables the implementation of the policies with social and economic feasibility of $r=0,62$ This means there is a fairly strong relationship between variables the implementation of the policies with resources. Because the value of $r$ correlation $>0$, meaning that a positive linear relationship occurs, the greater the value of the variable implementation of policies with social and economic feasibility. Then for the value of the coefficient determination is $46 \%$ describe there is a fairly strong influence between the implementation of policies with social and economic feasibility. The value of the test statistic t-value showed significant yield 6.81 ( $\mathrm{H} 0$ is rejected for testing the hypothesis of influence between the implementation of policies with social and economic feasibility obtained tcount $=>6.81$ ttable, then Ho is rejected, meaning that there is influence the implementation of policies with social and economic feasibility.

- The coefficient component between the variable policy implementation with the disposition of the showed by the value $r=0.57$, this means there is a fairly strong relationship between variable policy implementation with political purposes. Because the value of $r$ correlation $>0$, meaning a positive linear relationship occurs, the greater the value of the variable policy implementation with the disposition. Then for the coefficients determinant of $29 \%$ describe there is a fairly strong influence among the implementation policies with the disposition. The value of the test statistic t-value 5.80 showed significant results ( $\mathrm{H} 0$ is rejected for testing the hypothesis of influence between the implementation of policies with the disposition of acquired tcount = ttable $>5.80$, then Ho is rejected, meaning that there is the influence of the policy implementation with the disposition.

- Component coefficient between variables implementation policies with the bureaucratic structure is indicated by the value of $r=0.41$, this means there is a strong link between the variable policy implementation with the management of the administration. Because the value of $\mathrm{r}$ correlation $>$ 0 , meaning a positive linear relationship occurs, the greater the value of the variable policy implementation with the bureaucratic structure. The value of the coefficient of determination is obtained amounted to $21 \%$ describing a fairly strong influence among the policy implementation with the bureaucratic structure. The value of the test statistic t-value 8.31 showed significant results ( $\mathrm{H} 0$ is rejected for testing the hypothesis of influence between the implementation of policies with the bureaucratic structure retrieved $=$ tcount $>8.1$ ttable, then Ho rejected, i.e. There is the influence of the implementation policy with the bureaucratic structure.

- The results of these calculations show that the dimensions variable implementation of policies has an important meaning for use in the measurement of the control area.

\section{2) Validation Of management Variables Measurement Model Invalid Constructs}

The results of the data processing by using LISREL 8.5 software for model measurement area management will be demonstrated variable in the following table:

Table 4.2 Model Measurement Variable Area Management

Table 4.2 Model Measurement Variable Area Management
\begin{tabular}{|c|c|c|r|r|}
\hline No & Equation & $\begin{array}{c}\text { Varanasi } \\
\text { errors }\end{array}$ & $\mathbf{R}^{2}$ value & $\begin{array}{c}\text { t Value } \\
(\text { min 1.96) }\end{array}$ \\
\hline 1 & $\begin{array}{c}\text { Y1 }= \\
\text { 0.44*Management }\end{array}$ & 0.71 & 0,32 & 2.19 \\
\hline 2 & $\begin{array}{c}\text { Y2 }=0.96^{*} \\
\text { Management }\end{array}$ & 0.68 & 0,28 & 9,94 \\
\hline 3 & $\begin{array}{c}\text { Y3 = 0.46* } \\
\text { Management }\end{array}$ & 0.12 & 0,21 & 10,69 \\
\hline 4 & $\begin{array}{c}\text { Y4 }=0.94^{*} \\
\text { Management }\end{array}$ & 0.07 & 0,19 & 10,87 \\
\hline
\end{tabular}
Source: Data Processing Results, 2019

Based on table 4.2, can be explained as follows:

- Component coefficient between variables area management with appropriate conditions the community $r=0.71$, this means there is a fairly strong relationship between variables with the appropriate district management condition of society. Because the value of $\mathrm{r}$ correlation $>0$, meaning a positive linear relationship occurs, the greater the value of the variable control region with the appropriate conditions of society. 
The value of the coefficient of determinants area with appropriate management conditions community being acquired for $32 \%$, this means that there is a very strong influence between management areas in accordance with the conditions of the community. The value of the test statistic t-value 2.19 shows significant results ( $\mathrm{H} 0$ is rejected for testing the hypothesis of influence between areas management in accordance with the conditions of the community obtained tcount $=$ ttable $>2.19$, then Ho is rejected, meaning that there is a management influence in accordance with the conditions of the community.

- Component coefficient between variables area management by meeting the needs of the service of $r$ $=0.68$, shows there is a very strong relationship between the variables area management by meeting the needs of the service. Because the value of $r$ correlation $>0$, meaning a positive linear relationship occurs, the greater the value of the variable area management by fulfilling the needs of the service. Then for the value of the coefficient of determinant by $28 \%$ describe there is a very strong influence among the control area with meeting the needs of the service. The value of the test statistic t-value 9.94 showed significant results ( $\mathrm{H} 0$ is rejected). To test the hypothesis of influence between the area management with meeting the needs of the Ministry obtained tcount $=$ ttable $>9.94$, then Ho is rejected, meaning that there is a management influence on the region by meeting the needs of the service.

- Component coefficient between variables area management with public perception and satisfaction $\mathrm{r}=0.12$, this means there is a fairly strong relationship between variable control region with the satisfaction and the perception of the community. Because the value of $r$ correlation $>0$, meaning a positive linear relationship occurs, the greater the value of the variable control region with the satisfaction and the perception of the community. Then for the coefficients determinant of $21 \%$ illustrates there is a strong influence among the control area with the satisfaction and the perception of the community. The value of the test statistic t-value 10.69 showed significant results (H0 is rejected). To test the hypothesis of influence between the area management with the satisfaction and the perception of society retrieved tcount $=$ ttable $>$ 10.69 , then Ho is rejected, meaning that there is the influence of the area management with the satisfaction and the perception of the community.

- Component Coefficient between variables area management by reducing the adverse impact of the community $r=0.07$, this means there is a very strong relationship between the variables controlling the region by reducing adverse impacts. Because the value of $r$ correlation $>0$, meaning a positive linear relationship occurs, the greater the value of the variable adverse with the area management harmful impact. Then for the coefficients determinant of $19 \%$ illustrates there is a strong influence among the control area by reducing the adverse impact. The value of the test statistic t-value 10.87 showed significant results ( $\mathrm{H} 0$ is rejected). To test the hypothesis of influence between the area management with the adverse impact of the acquired area tcount $=$ ttable $>2.79$, then Ho is rejected, meaning that there is a management influence on the region by reducing adverse impacts.

3) 4.1.3. Validation of The Measurement Variables Model Invalid Constructs the Implementation of Policies Towards the Effectiveness of the Controlling Area

The results of the data processing by using LISREL 8.5 software to model the measurement variable policy implementation against the area management will be shown on the following table:

Table 4.3 Variable Measurement Model to Policies Implementation Against the \begin{tabular}{|c|c|c|}
\hline \multicolumn{2}{|c|}{ Area Management } \\
\hline Equation & $\mathbf{R}^{2}$ value & $\begin{array}{c}\text { t Value } \\
(\mathbf{m i n} 1.96)\end{array}$ \\
\hline management $=0.77$ * policy implementation & 59,29 & 7,64 \\
\hline
\end{tabular}

Source: Data Processing Results,2019

The coefficient of the variable component between the policy implementation against the area management $r=$ 0.77 . Because the value of $\mathrm{r}$ correlation $>0$, meaning a positive linear relationship occurs, the greater the value of the policy implementation against the region management. Then for the coefficients determinant of $59.29 \%$, meaning that there is a fairly strong influence between the policies implementation towards the region management. Measurement of significance to test the hypothesis of influence between the policies implementation towards the region management retrieved tcount $=$ ttable $>7.64$, then there was significant influence between the policies implementation towards the effectiveness of the area management. The results of these measurements indicate that there are other variables of $40.71 \%$ that affect the region management against variables that is not examined in this study. The high influence of the policy implementation against the effectiveness of the area management is expected to provide a positive impact on land over the function changes that occur in the Kecamatan Cimenyan so that the end goal of the policy implementation can be achieved.

The results of descriptive analysis and interviews with the responsible parties for the implementation, obtained a general overview that policy implemented in Peraturan Daerah Provinsi Jawa Barat Nomor 2 Tahun 2016 as the main factor that expected to provide improvements towards the land function arrangement in the region of KBU. Indications of improvement are shown from the factors that play a huge role in policy implementation i.e. communication, resources, disposition and bureaucratic structure.

The results of the descriptive analysis show the influence of the factor of $48 \%$, communication resources amounting to $46 \%, 32 \%$ and the disposition of the factor structure of the bureaucracy by $28 \%$. From

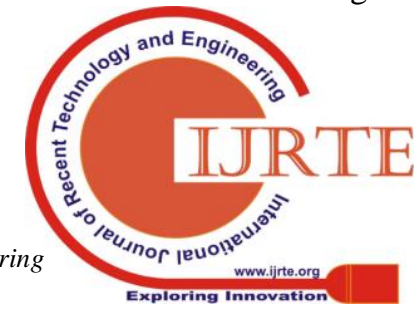


this descriptive analysis results can be analysed that in general area management policy implementation are conducting to some level however bureaucratic structure is still less well perceived by most respondents. So, in an effort to improve land management, need to make repairs on a bureaucratic structure that includes aspects of the clarity on description of the work and the Division of labour, the clarity in standard operating procedure as well as the existence of cooperation/coordination between work units. Related efforts are improvements on the effectiveness of the area management will be reflected in the existence of a community dimension to improvements in conditions, Service accomplishment category, Citizen or client satisfaction and perception and Unintended adverse impact of a service on the community. The results of the descriptive analysis showed the influence to achieve a community dimension conditions 32\%, dimensions of Service accomplishment category by $28 \%$, the dimensions of Citizen or client satisfaction and perception, amounting to $21 \%$, dimensions of Unintended adverse impact of a service on the community of $19 \%$.

Dimensions of communication is part of the public policy information needs to be given to implementing the policy. Edwards III States that it is aimed so that the executant can know and understand what the content, purpose, direction and target group (target group) policy so that the executant can prepare properly what should prepared and performed in carrying out public policy so that what the policy goals and objectives can be achieved with the expected ". Thus, communication is an important factor in understanding the implementation of policy. Through the communication achievement of goals will be more easily achieved, communication can also facilitate Member organizations in conducting cooperation and likened the perception in order to achieve the goals of the organization. Based on the results of data analysis and the results of interview shows in general communications conducted within the framework of the implementation of the policy has not been done well. In queue with the opinion of Edwards III stating that "Policy implementation, ... is the stage of policy making between the establishment of a policy ... and the consequences of the policy for the people whom it affects." The formula contains the meaning that the real policy implementation is the implementation of a programmed aimed at achieving the objectives of the policy.

The results showed that often information related to the Organization policy and the guidelines or guidance activities obtained less complete. This often raises the vagueness about what information and how the content policies that concern both the institutional regulations, procedures or systems. In addition, the information obtained the policy implementers often less accurately so as to encourage the implementers take action very loose in interpreting and implementing the policy. Barriers and distortions of such communications should be reduced, because the more that must be reached by communication then it would more likely lost the meaning intended by the policy. Similarly, the more layers of bureaucracy that should be skipped, then the greater the opportunities for neglected and distortion on policy meaning. To that end, the better developed the channel communication channels to pass on the command implementation, will give positive probability level against access policy to be forwarded correctly.

Dimension resources not only includes human resources/sheer civil servant but also encompassed the Authority managing civil servant and also control policy implementation support facilities of the area. While Edward III (1980:10) complements that in addition to the availability of a sufficient amount in "We must evaluate the bureaucracy not only in term of absolutely number but also in terms of its capabilities to perform desired task". The results showed resource factors in general are still rated less well. This is apparent from the number of managing authorities who judged still inadequate seen in quantity. The results of the Research Division of the number of employees between the section number is highly variable, if you see a load of work that is the responsibility of each section relative almost the same. These conditions show that the Division of the number of employees should consider an analysis of the workload on each section based on basic tasks and functions.

In carrying out the functions of the Ministry at the community and anticipate the problems of an increasingly complex development issues, local government district/city of interested parties to be able to develop the ability of the State civil servant so that it can work in Professional. The issue of quality improvement resources civil servant has a value is important because it is believed that with the professional civil servant every job that has been planned to be resolved properly. Smith suggests that the quality of personnel who implement policies is very important because the less or no personnel quality will reduce the capacity of the implementation. Personnel variable according to Smith has two characteristics that must be met in order to be implementing good policies including:

1) Where a sufficient amount of charge indicators will be the number of personnel compared with the workload, the number of target group and area;

2) Have the ability corresponding to the type of work. Its capabilities include a number of indicators such as: the ability of engineering, managerial ability, understanding of the substance of the policies to be implemented as well as attitude/behaviour (attitude) i.e. the desire and sense of responsibility for the success of implementation.

In the context of the availability or quality of, the institutions implementing policies still face constraints with regard to:

a) The low ratio of officer Manager policy;

b) Welfare level is still low as well as allowances that can afford given the still limited; Welfare level is still low as well as allowances that can afford given the still limited;

c) The professionalism of HUMAN RESOURCES is still low so need to have continuously increased the quantity and quality of the civil servant in accordance with Environment Manager task demands and increasing institutional 
capacity.

Edward III States that "in the implementation of policies required Standard Operating Procedure (SOP) to be used as guidelines, instructions, guidance and reference for policy makers so that they know what to prepared and conducted, who the targets and what to be achieved from the implementation of these policies. "Not obviously SOP regarding the mechanisms, systems and procedures of implementation of the policy, Division of basic tasks, functions, authorities and responsibilities between the implementer, inharmonious the relationship between the implementing organization will also participate determine the failure of implementation of policies.

In general, the implementation of policies linked to the bureaucratic structure assessed less well specifically related to the job description and cooperation between related parties in this case shows that cooperation in the context of the implementation of the policy is not yet fully effective, resulting in delays in process control and the impact thereof on society. Results also found yet effective clarity Division of labour in the implementation of the policy of control of the area. A formal Division of labour has had certainty thus providing clarity for civil servant in carrying out his duties and functions appropriate basic tasks, but operationally effective yet appropriate to the potential resources that belong to good human resources nor the support facilities.

On the other hand, the application of bureaucratic structure in the context of the implementation of work in the implementation of the policy of control of land shows the lack of compliance of the civil servant against Standard Operating Procedure (SOP) in accordance with the standards set. This is shown by the phenomenon tends to be easy it issued permits for developers who do land development activities into the housing at almost the entire territory of Cimenyan Sub-district. To date no less than 30 developers doing development in the region.

The tendency of the implementing authorities attitude shows how far is the commitment of institutions (institutional commitment) in implementing the policy. In this context, Bardach stated that the necessary commitment is concerned .... form both and below. Not only top administrators, but office and field staff as well must be committed to policy implementation. Institutional commitment will be reflected from the trend of implementing institutional reform policy stance towards the control of the region. The strong commitment of the institutions involved in the control of the region appears to have not yet reached satisfactory condition until this immature, whereby each party looked at the question of the control of the area from the corners of each interest, not come to the realization on the meaning and importance of joint control of the area for the community. It is apparent from the various adverse impact control efforts over the function of the land while already touched on political areas that need support/commitment of the leadership of the County/City Government related, overlapping tendencies granting permission land use between the City Government, district or province also became another obstacle that shows still weak commitment to implementing policy officials.

On the other side of the assessment of the policy can be reviewed on the efforts in cooperation with district/city nearby in the implementation of the policy of controlling the region have not developed optimally for the implementation of the entire programmed that planned. Cooperation between local governments is an issue that needs to be noted the current Government given its role in determining the success of overcoming the problems faced by the whole region, and see many of the problems and needs of the community in areas that need to be addressed or fulfilled by crossing the boundaries of administrative areas. To make this cooperation required the identification of strategic issues, shape or precise cooperation model, and the principles that guide the success of such cooperation. Given the strategic role played in the control area of the province in the region of $\mathrm{BKU}$, then an increase in the role and capabilities of this cooperation mechanism in the province include the adjustment of the structure and function of its organization should be the agenda of the Government in the future. If there are no new breakthroughs in efforts to handle and reduces inequality land use. The question of area management associated with land use deviations are then implies interruption environment that is detrimental to society.

To prevent the wider impact of unwanted these necessary efforts for tackling both resting on aspects of communication in the utilization and management of land, institutional (the implementing institution), financing aspects, aspects environment, as well as the legal aspects as a result of any such breach or deviation towards the policies that have been set. Every step towards the development strategy and the environmental demands in addition to extend benefits to the fulfilment of people's life should be able to minimize the risk or loss that will arise. Another important thing is about the importance of legal aspects to be used as guidelines in the form of regulations regarding the environment for the sake of tackling environmental damage caused by the use of the land.

\section{CONCLUSION}

From the results of research conducted can be drawn the following conclusions: 1 . The extent of influence in the policy implementation against the area management in Kecamatan Cimenyan, Kabupaten Bandung is determined by the dimensions of communication, resources, disposition or the attitude of the executor and the bureaucratic structure that is very significant. 2. The largest dimension of policies implementation that affect the area management is communication. 3. The largest dimension of area management that most affected by the policy implementation is the Community Condition.

And based on the conclusions and findings in research, proposed the following suggestions: 1 . To enhance the effectiveness of area management, the need to increase the communication 
dimensions either in quality or in quantity, an increase resources, disposition/support and bureaucratic structure. 2 .

To improve the officer's performance, they needed skills training, increased the number of personnel as well as the addition of the means of implementation of the policy. 3 .

Increase the personal commitment of the implementing authorities and officials in particular in the granting of a permit as well as the participation of the community in the control of the region. 4. Strict reprimand against violations of land development in KBU region, specifically Kecamatan Cimenyan Kabupaten Bandung in accordance with the allocation of functions and cultivation areas or protected areas. 5. To reduce inequality and land use in the area of $\mathrm{KBU}$, a new breakthrough is needed in the form of an increase in the role and capabilities of the province as an important agenda of Government policy in the future.

\section{REFERENCES}

[1] J. E. Anderson, Public Policy Making, New York: Holt Rinehart and Winston, 1969.

[2] T. R. Dye, Understanding Public Policy 7th edition, Englewood Cliffs New Jersey: Prentice Hall, 1992.

[3] Y. Dror, Public Policy Making, Re-examined, Seraton, PA: Chandler, 1968

[4] W. N. Dunn, Public Policy Analysis : An Introduction, New Jersey: Prentice Hall Inc., 1994.

[5] D. Easton, A System Analysis of Political Life, New York : John Wiley, 1965

[6] D. Easton and I. Sharkansky, The Policy Predicament, San Fransisco: WH Freeman and Company, 1978

[7] J. Donahue and J. S. Nye Jr., For The People: Can we Fix Public Service, Washington DC: Brooking Institution Press, 1997.

[8] G. C. Edward III, Implementing Public Policy, Washington DC: Congressional Quarterly Inc, 1980.

[9] P. D. Epstein, Using Performance Measurement in Local Government. A Guide To Improving Decisions, Performance and Accountability, New York: National Civic League Press, 1988

[10] A. Ferdinand, Structural Equation Modelling dalam Penelitian Manajemen, Semarang: Fakultas Ekonomi UNDIP, 2002

[11] W. L. Hays, Qualification in Psychology, New Delhi: Prentice Hall of India, 1969.

[12] Kerlinger, Foundation of Behavioral Research, New York: Holt Rinehart and Winston Inc, 1986.

[13] P. Wayne, Public Policy: An Introduction to The Theory and Practice of Policy Analysis, Cheltenham-Lyme US: Elgard Publishing Ltd., 2001.

[14] S. Rustiadi E and P. S, Perencanaan dan Pengembangan Wilayah, Jakarta: Yayasan Obor Indonesia-Crestpent Press, 2009.

[15] B. Winarno, Teori dan Proses Kebijakan Publik, Yogyakarta: Media Pressindo, 2002

[16] R. Indonesia, "Undang-Undang Nomor 32 tentang Pemerintahan Daerah," Fokus Media, Bandung, 2004

[17] R. Indonesia, "Undang-undang nomor 9 Tentang Perubahan Kedua Atas Undang-undang Nomor 23 Tahun 2014 Tentang Pemerintah Daerah,” Citra Umbara, Bandung, 2015.

[18] M. K, S. Sitorus, R. E., G. K. and Hartrisari, "Dampak Perubahan Penggunaan Lahan Terhadap Erosi di DAS Cidanau, Banten,” Jurnal Tanah dan Iklim, 32, pp. 55-69, 2010.

[19] P. Jabar, "Peraturan Daerah Provinsi Jawa Barat Nomor 2 Tentang Rencana Tata Ruang Wilayah," Pemda, Bandung, 2016.

[20] C. Y. Patton and D. S. Sawicki, Basic Method of Policy Analysis and Planning, New York: Prentice Hall - Englewood Cliffs, 1986.

[21] L. W. Neuman, Basic of Social Research Qualitative and Quantitative Approaches 2nd Edition University of Winsconsin, Whitewater-USA: Pearson Education Inc, 2007.

[22] T. A. Smith, The Comparative Policy Process, Santa Barbara-California: ABC-CHO, 1975.

[23] D. J. Mueller, Measuring Social Attitudes: A Handbook for Researchers and Practitioners, USA: Teachers College Press, 1986.

\section{AUTHORS PROFILE}

My name is Tati Sarihati, I am from Government Sciences program, Fakucty of Social and Political Sciences Universitas Langlangbuana Bandung Indonesia and my area of interest is political science.

My name is Rannie Dyah K.Rachaju, I am associated with Communication Sciences program, Fakucty of Social and Political Sciences Universitas Langlangbuana Bandung Indonesia and my area of interest is political science.

I am Lusy Mukhlisiana, I am from Communication Sciences program, Fakucty of Social and Political Sciences Universitas Langlangbuana Bandung Indonesia and my area of interest is political science. 